\title{
LITERASI KEUANGAN SYARIAH DI PONDOK PESANTREN AL-JADID, KECAMATAN KOPO, KABUPATEN SERANG
}

\section{SHARIA FINANCIAL LITERACY AT AL-JADID ISLAMIC BOARDING SCHOOL, KOPO DISTRICT, SERANG REGENCY}

\author{
Ade Nur Rohim*, Prima Dwi Priyatno, Lili Puspita Sari \\ Universitas Pembangunan Nasional Veteran Jakarta \\ *Email: adenurrohim@upnvj.ac.id \\ (Diterima 14-09-2021; Disetujui 24-09-2021)
}

\begin{abstract}
ABSTRAK
Indonesia merupakan salah satu negara dengan populasi muslim terbesar di dunia. Di era disrupsi seperti saat ini, generasi milenial merupakan generasi yang memainkan peranan penting dalam berkontribusi terhadap program pemerintah. Salah satu program yang dicanangkan adalah pengembangan keuangan syariah nasional. Di sisi lain, tingkat literasi dan inkluasi keuangan syariah masih sangat rendah. Program pengabdian kepada masyarakat ini bertujuan untuk mengedukasi dan mensosialisasikan kepada masyarakat, khususnya di tingkat pelajar terkait ekonomi dan keuangan syariah, sehingga dapat mendorong peningkatan literasi dan keuangan syariah di masyarakat. Kegiatan ini dilakukan dalam bentuk tes pendahuluan, pemaparan, diskusi dan tanya jawab, serta tes penutup. Kegiatan dilakukan secara online dengan memanfaatkan platform Google form dan Google meet. Kegiatan ini menghasilkan peningkatan pemahaman peserta terkait prinsip dasar dan pengembangan ekonomi dan keuangan syariah. Melalui kegiatan ini, direkomendasikan untuk dilakukan kegiatan edukasi dan sosialisasi ekonomi dan keuangan syariah yang berkelanjutan kepada berbagai unsur masyarakat.
\end{abstract}

Kata kunci: literasi, keuangan syariah, pesantren

\section{ABSTRACT}

Indonesia is one of the countries with the largest Muslim population in the world. In this era of disruption, the millennial generation is a generation that plays an important role in contributing to government programs. One of the programs launched is the development of national Islamic finance. On the other hand, the level of Islamic financial literacy and inclusion is still very low. This community service program aims to educate and disseminate material to the community, especially at the student level, regarding Islamic economics and finance, so as to encourage the improvement of Islamic literacy and finance in the community. This activity is carried out in the form of preliminary tests, presentations, discussions and questions and answers, and closing tests. Activities are carried out online by utilizing Google forms and Google meet platforms. This activity resulted in an increase in participants' understanding of the basic principles and development of Islamic economics and finance. Through this activity, it is recommended to carry out educational activities and socialization of sustainable sharia economy and finance to various elements of society.

Keywords: literacy, sharia finance, pesantren

\section{PENDAHULUAN}

Indonesia merupakan negara dengan karakteristik demografi yang menarik. Selain memiliki penduduk muslim dengan persentase terbesar di antara agama lainnya, pada tahun 2030-2040, Indonesia juga diprediksi memiliki bonus demografi, yaitu jumlah penduduk usia produktif (usia 15-64 tahun) lebih besar dibandingkan dengan penduduk dengan usia tidak produktif (di bawah 15 tahun dan di atas 64 tahun). Pada periode tersebut, penduduk dengan usia produktif diprediksi akan mencapai 64\% dari jumlah penduduk yang diproyeksikan sebesar 297 juta jiwa (Afandi, 2017). 
Penduduk Indonesia yang termasuk kategori usia produktif dan sedang naik daun saat ini adalah generasi milenial. Generasi milenial adalah mereka yang lahir pada kisaran 1980 hingga 2000-an (Rachmat et al., 2020). Generasi ini diidentikkan dengan kemajuan teknologi dan informasi beserta segala kemudahannya. Generasi ini lahir di tengah disrupsi teknologi yang di sisi lain memudahkan mereka mengakses berbagai macam informasi dengan cepat.

Generasi milenial adalah generasi pertama yang tumbuh dengan komputer dan internet. Pesatnya perkembangan teknologi ini telah merubah gaya hidup generasi milenial dibandingkan dengan generasi sebelumnya. Penelitian yang dilakukan oleh Centre for Strategic and International Studies tahun 2017 menyatakan bahwa dari aspek kegiatan yang diminati, generasi milenial lebih tertarik dengan kegiatan olahraga dan musik. Berbeda dengan generasi non milenial yang lebih tertarik pada kegiatan keagamaan dan memasak. Dari aspek sumber kebahagiaan, generasi milenial tidak memasukkan kecukupan keuangan sebagai indikator kebahagiaan mereka. Mereka lebih bahagia dengan waktu luang yang dimiliki bersama keluarga. Berbeda dengan generasi non milenial yang menaruh atensi cukup tinggi terhadap kecukupan keuangan mereka (Centre for Strategic and International Studies, 2017).

Dalam membelanjakan keuangan, secara umum masyarakat akan menggunakannya untuk konsumsi, maupun untuk investasi. Rendahnya pengetahuan masyarakat tentang industri keuangan beserta produk-produknya menyebabkan masyarakat mudah terjebak dalam melakukan investasi yang menawarkan keuntungan yang menggiurkan dalam jangka waktu yang pendek tanpa mempertimbangkan risikonya (Said \& Amiruddin, 2017).

Berbagai data dan hasil riset tersebut membuktikan bagaimana gaya hidup (life style) generasi milenial telah mulai mengarah pada budaya konsumtif. Mayoritas saat ini lebih memilih untuk menghabiskan uangnya untuk membeli barang koleksi yang lucu dan unik, nonton bareng teman, makan-makan di kafe dan lainnya. Fakta ini begitu kontradiktif dengan kenyataan bahwa generasi milenial adalah mereka yang hidup di usia produktif. Seharusnya, usia produktif yang dimiliki generasi milenial ini diimbangi dengan pendidikan keuangan yang baik agar sikap dan perilakunya juga menunjukkan sikap dan perilaku produktif.

Pendidikan keuangan yang diberikan orang tua, pengalaman bekerja dan wirausaha serta pendidikan yang diterima di sekolah dapat menjadi faktor pembentukan karakter generasi milenial tersebut. Pada tahun 2019, Otoritas Jasa Keuangan (OJK) melakukan survei kepada masyarakat yang memiliki usia kisaran 15 sampai di atas 50 tahun dengan 
total responden mencapai 12.773 orang yang tersebar di 34 provinsi dan 67 kota/kabupaten. Hasil survei tersebut menyatakan bahwa indeks literasi keuangan konvensional pada tahun tersebut hanya sebesar 38,03\%, dan indeks inklusi keuangan mencapai 76,19\% (Otoritas Jasa Keuangan, 2019). Sementara indeks literasi keuangan syariah baru mencapai $8,93 \%$.

Data ini menunjukkan bahwa pengetahuan dan pemahaman masyarakat terhadap sektor-sektor lembaga keuangan syariah masih sangat rendah dan hal ini tentunya harus menjadi perhatian semua pihak terkait untuk melakukan edukasi dan literasi tentang keuangan syariah. Minimnya literasi keuangan khususnya keuangan syariah ini tentu membuat generasi milenial merasa sulit untuk mengatur keuangan. Sebagian milenial juga masih sulit mengatur keuangannya sesuai skala prioritas.

Untuk memperbaiki sikap keuangan remaja maka diperlukan strategi dan program kongkrit untuk meningkatkan literasi keuangan khususnya syariah karena dapat membentuk sikap anak menjadi tangguh dan siap untuk hidup di masyarakat luas. Pendidikan literasi keuangan harus diberikan sedini mungkin kepada anak terutama pada anak usia pra sekolah dan sekolah dasar. Sebab, pengenalan terhadap pengetahuan literasi keuangan sejak dini akan membuat anak-anak terbiasa mengelola keuangan dengan baik dan benar di masa yang akan datang (Senjiati et al., n.d.).

Beberapa hasil riset tersebut menjadi pijakan dalam pelaksanaan kegiatan pengabdian kepada masyarakat ini. Mitra sasaran masyarakat dalam kegiatan Pengabdian Kepada Masyarakat ini adalah masyarakat yang tidak produktif secara ekonomi, yaitu santri Pondok Pesantren Al-Jadid, Kecamatan Serang, Banten.

Sebagai daerah pecahan dari Jawa Barat yang ditetapkan pada tanggal 6 Oktober 2000 melalui Undang-Undang Republik Indonesia Nomor 23 Tahun 2000, Pemerintah Provinsi Banten memiliki perhatian penuh dalam melaksanakan pembangunan pendidikan. Salah satu komitmen yang dibangun adalah mengotimalkan layanan pendidikan. Diharapkan dengan adanya kegiatan Pengabdian Kepada Masyarakat dengan tema Literasi Keuangan Syariah ini, dapat memberikan meningkatkan aqidah, syariah dan akhlaq peserta serta peningkatan sikap, pengetahuan dan ketrampilan dalam meningkatkan wawasan pengelolaan harta Islami sejak dini di Pondok Pesantren Al-Jadid sehingga dapat menciptakan generasi yang memiliki karakter yang unggul dalam pengembangan ekonomi dan keuangan syariah di masa mendatang.

Selain itu, peningkatan Literasi Keuangan Syariah juga dapat memperluas akses permodalan pada lembaga keuangan syariah (Otoritas Jasa Keuangan, 2017). Diharapkan 
dengan adanya kegiatan Pengabdian Kepada Masyarakat dengan tema Literasi Keuangan Syariah ini, dapat memberikan kontribusi dalam peningkatan indeks literasi keuangan syariah di kalangan masyarakat non produktif, terutama untuk masyarakat di lingkungan sekolah dasar dan menengah. Sehingga, pendidikan literasi keuangan khususnya keuangan syariah dapat diberikan sedini mungkin untuk membentuk pengetahuan yang baik dan karakter yang unggul dalam pengelolaan keuangan di masa mendatang.

\section{BAHAN DAN METODE}

Kegiatan pengabdian ini dilakukan di Pondok Pesantren Al-Jadid yang berlokasi di Kp. Calingcing Ds. Kopo Kec. Kopo Serang, Provinsi Banten. Sekolah tersebut merupakan pondok pesantren yang dimiliki oleh yayasan yang berdiri pada tahun 2006. Saat ini sekolah sudah terakreditasi B.

Metode yang digunakan dalam kegiatan pengabdian kepada masyarakat ini dilakukan dalam beberapa tahapan, antara lain:

1. Melakukan audiensi kepada Kepala Pondok Pesantren Al-Jadid untuk mengetahui profil civitas akademik yang ada di lingkungan sekolah, baik tenaga pendidik, tenaga kependidikan dan para santri/santriwati. Audiensi dilakukan secara korespondensi melalui Whatsapp melalui pengurus di Pondok Pesantren Al-Jadid.

2. Memberikan pre-test kepada para peserta, hal ini dilakukan untuk mengetahui dan mengukur sejauh mana pengetahuan peserta tentang literasi keuangan syariah. Proses ini dilakukan sebagai pembuka dan awal kegiatan. Tahapan ini dilakukan dengan platform Google form.

3. Melakukan sosialisasi dalam bentuk seminar/ceramah. Materi yang diberikan tentang ekonomi dan keuangan syariah. Dengan pelaksanaan pengabdian di tengah pandemi, kegiatan sosialisasi dilakukan secara virtual dengan menggunakan platform Google meet.

4. Memberikan post-test kepada peserta, hal ini dilakukan untuk mengetahui dan mengukur pengetahuan dan pemahaman peserta tentang literasi keuangan syariah yang telah diberikan, sekaligus untuk mengetahui dan mengukur tingkat keberhasilan pelaksanaan kegiatan. Dalam hal pelaksanaannya, post-test juga dilakukan dengan platform Google form. Hasil capaian penilaian peserta dalam post-test digunakan untuk mengukur keberhasilan kegiatan dalam upaya meningkatkan pemahaman peserta terkait materi yang disampaikan. 


\section{HASIL DAN PEMBAHASAN}

Kegiatan pengabdian ini dilakukan dalam bentuk sosialisasi kepada santri Pondok Pesantren Al-Jadid. Hal ini didasari karena pentingnya upaya peningkatan literasi keuangan syariah kepada masyarakat, khususnya di kalangan milenial, seperti para santri pondok pesantren. Melalui kegiatan ini, para santri nantinya akan turut mengembangkan ekonomi dan keuangan syariah, baik secara teoritis maupun secara praktis.

Kegiatan diawali dengan melakukan tes pendahuluan (pre-test). Langkah ini dilakukan untuk mengukur tingkat pemahaman awal para peserta terkait materi yang akan disampaikan. Gambar 1 menunjukkan bahwa secara rata-rata, pada skala 100, nilai ratarata tes pendahuluan peserta adalah 55.71. Angka ini menunjukkan bahwa tingkat pemahaman dan literasi para peserta masih terbilang cukup rendah. Data nilai tersebut tersebar di kisaran nilai 30 dan 40, serta di kisaran nilai 70. Untuk nilai tes pendahuluan, terlihat bahwa nilai tertinggi yang diraih peserta adalah 80 . Data ini menunjukkan perlunya kegiatan sosialisasi dan edukasi kepada para peserta untuk meningkatkan pemahaman dan tingkat literasi terkait ekonomi dan keuangan syariah.

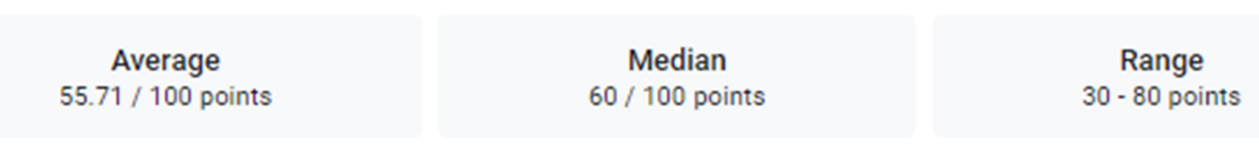

Total points distribution

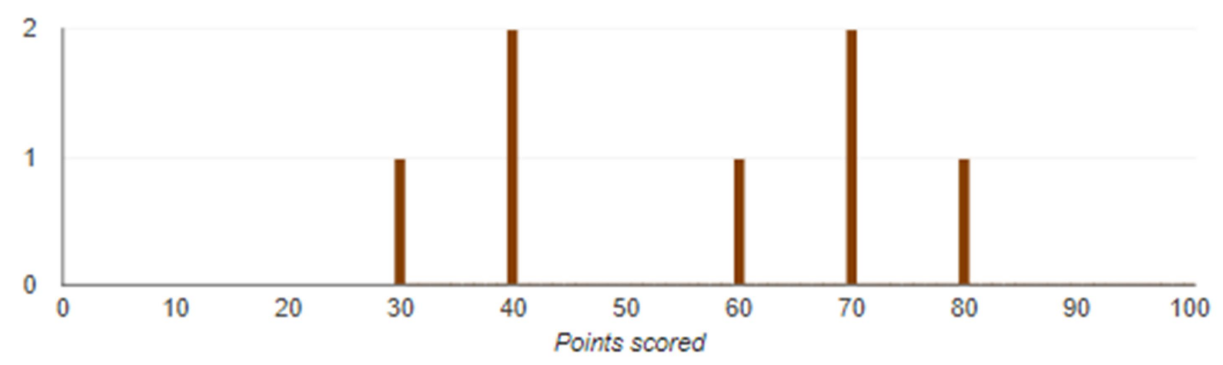

Gambar 1. Nilai Tes Pendahuluan (Pre-Test)

Keuangan syariah merupakan salah hal yang umumnya diimplementasikan di lingkungan pondok pesantren. Dalam aktivitas transaksi sehari-hari, para santri melakukan belanja di koperasi atau kantin pondok. Hal ini menunjukkan bahwa para santri telah melakukan aktivitas ekonomi dalam kesehariannya. Selain itu, dari sisi keilmuan, para santri juga telah dibekali oleh para guru dengan diajarkan mata pelajaran yang berhubungan dengan ekonomi dan keuangan syariah, seperti fiqih maupun ekonomi. Oleh karenanya diperlukan upaya peningkatan kapasitas para santri dalam memahami transaksi 
ekonomi dan keuangan syariah yang dipraktekkan dengan mengacu kepada prinsip-prinsip dasar syariah dan ekonomi yang telah dipelajari di kelas.

Peningkatan kapasitas dan pemahaman para santri dilakukan dengan menyampaikan materi terkait prinsip dasar keuangan syariah. Gambar 2 menunjukkan beberapa prinsip dasar keuangan syariah yang mencakup keadilan, keseimbangan, maslahat, instrumen zakat, dan bebas dari maysir, gharar, dan riba. Prinsip-prinsip dasar ini penting untuk diketahui oleh para santri sebagai pelaku ekonomi. Dalam penerapannya para santri dapat mengindentifikasi hal-hal yang tergolong transaksi yang halal dan haram di dalam aktivitas ekonomi sehari-hari. Prinsip tersebut diwujudkan dengan mengamalkan segala kegiatan dengan berorientasi pada maslahat, baik untuk dirinya, keluarganya, maupun masyarakat lain di sekitarnya.

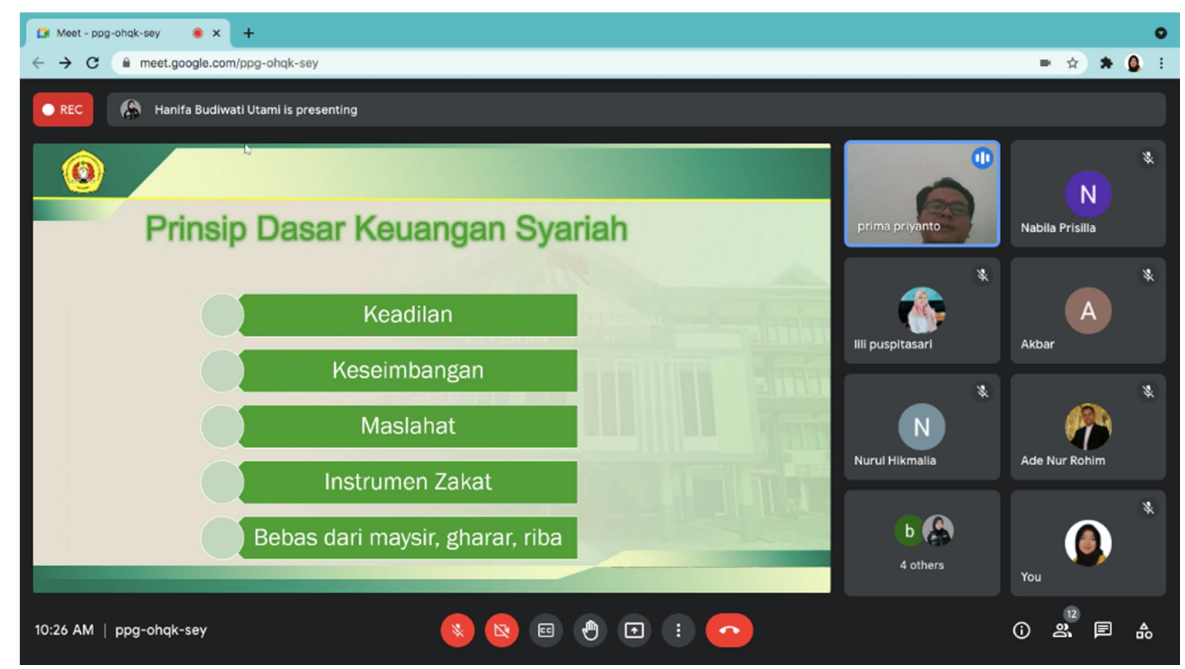

Gambar 2. Penyampaian Materi Prinsip Dasar Keuangan Syariah

Dalam pengembangan ekonomi dan keuangan syariah nasional, pemerintah telah menetapkan cetak biru pengembangan ekonomi dan keuangan syariah (Bank Indonesia, 2020). Dalam kegiatan pengabdian ini, para santri dikenalkan dengan berbagai program unggulan pemerintah dalam mengembangan ekosistem keuangan syariah di Indonesia. Target akhir dari program tersebut adalah cita-cita Indonesia untuk menjadi pusat ekonomi dan keuangan syariah dunia. Sebagai salah satu upaya dalam mencapai target dan cita-cita tersebut, adalah program penguatan literasi, riset, dan edukasi keuangan syariah. Program pengabdian ini dilakukan sebagai implementasi dari salah satu bentuk kegiatan edukasi dan sosialisasi keuangan syariah kepada masyrakat, khususnya di kalangan santri pondok pesantren sebagaimana ditunjukkan Gambar 3. 


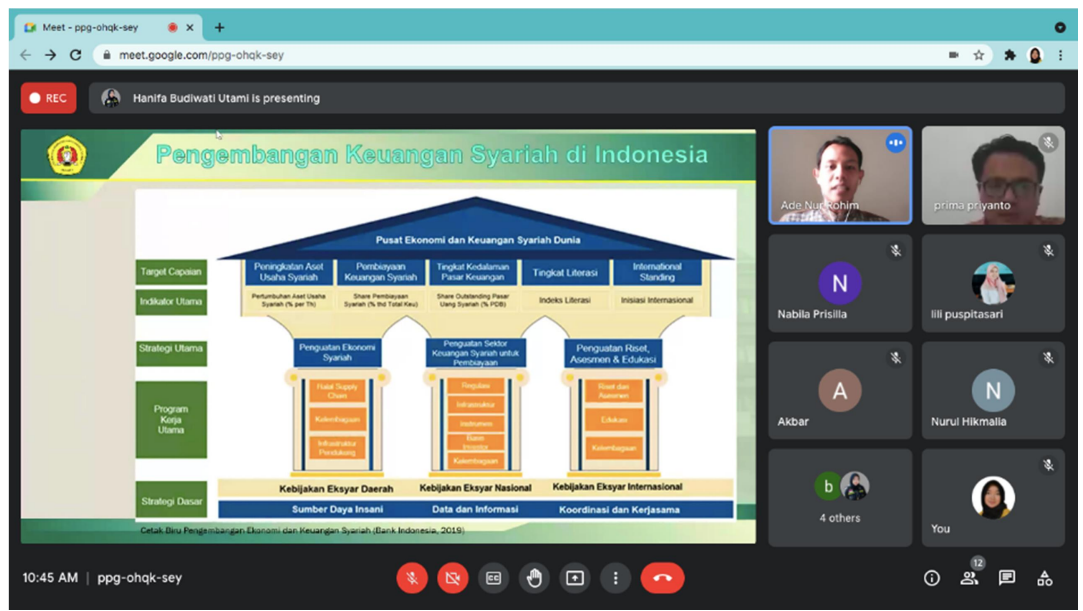

Gambar 3. Penyampaian Cetak Biru Pengembangan Keuangan Syariah Nasional

Dalam pemaparan yang dilakukan, disampaikan pula bahwa dalam pengembangan keuangan syariah nasional, Pemerintah telah menggandeng berbagai pihak. Berbagai pihak tersebut mencakup institusi pendidikan, lembaga swadaya masyarakat, organisasi massa Islam dan keumatan, hingga lembaga keuangan. Selain itu, upaya pengembangan tersebut juga melibatkan pihak-pihak dari unsur praktisi filantropi Islam, seperti lembaga zakat dan pengelola wakaf.

Lembaga keuangan syariah juga dikenalkan kepada para santri. Lembaga Keuangan Syariah yang mencakup lembaga perbankan syariah, dan juga lembaga keuangan syariah non-bank, dengan mengacu kepada dwi fungsi perbankan syariah. Sebagaimana yang telah diamanatkan oleh Undang-Undangan tentang Perbankan Syariah, bank syariah menjalankan fungsi komersial dan juga fungsi sosial. Hal ini menjadi kunci utama yang membedakan antara lemabaga keuangan bank syariah dan konvensional.

Secara tanggung jawab pribadi, para santri memainkan peran penting dalam mengelola keuangannnya agar sesuai dengan prinsip syariah. Gambar 4 menunjukkan halhal yang menjadi landasan bagi para santri dalam melakukan perencanaan dan pengelolaan keuangannya agar tidak menyalahi ketentuan syariah. Beberapa landasan tersebut antara lain aktivitas pembelanjaan harta yang sesuai dengan kebutuhan dan tidak bersifat boros dalam belanja. Selain itu, aspek halal dan haram juga dikedepankan dalam memilih barang dan makanan yang akan dikonsumsi. Pola konsumsi Islami yang diimplementasikan akan mengembangkan produksi barang dan makanan halal, yang secara selaras juga turut mengembangkan industri perbankan syariah dalam peningkatan pembiayaan maupun permodalan di sektor produksi halal. 


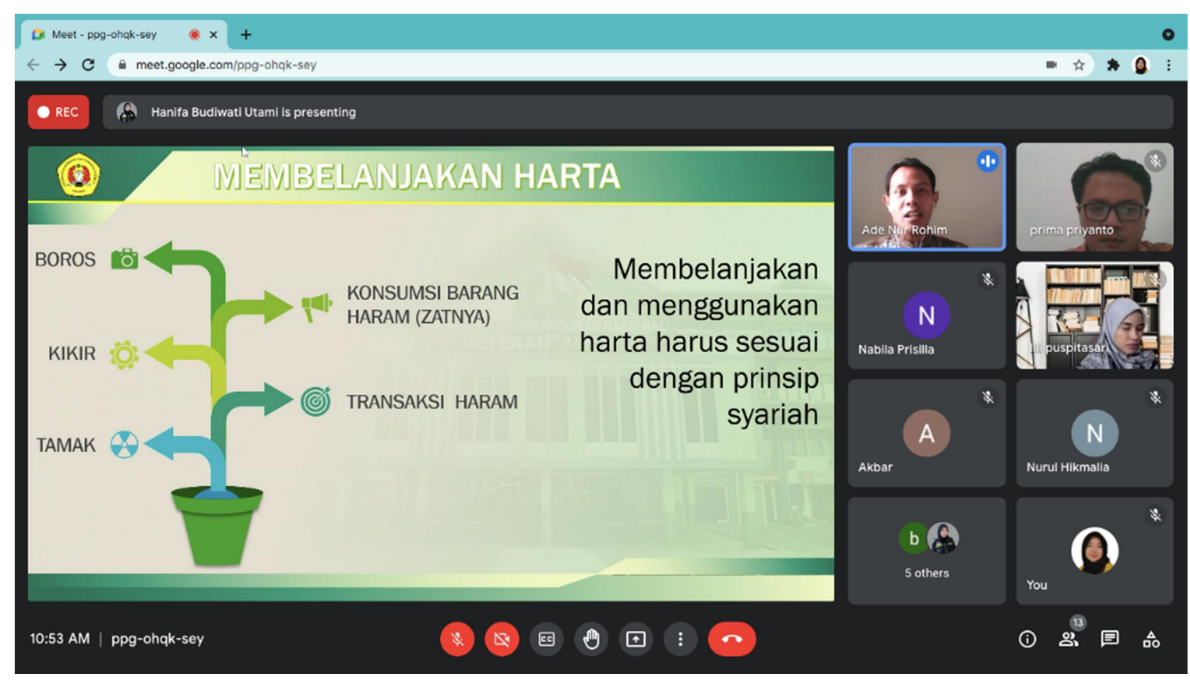

Gambar 4. Edukasi Batasan Syariah dalam Membelanjakan Harta

Sesi kegiatan pengabdian ini ditutup dengan sesi post-test. Sesi tes penutup ini dilakukan untuk mengukur ketercapaian target peningkatan pemahaman para santri terkait materi yang disampaikan. Dari Gambar 5 terlihat bahwa pemahaman para santri terkait materi paparan ekonomi dan keuangan syariah telah mengalami peningkatan. Dari capaian nilai yang diperoleh peserta, terdapat peserta yang mendapatkan nilai 100 (sempurna). Hal ini menjadi indikator adanya peningkatan, dimana pada sesi tes pendahuluan, belum ada peserta yang mencapai nilai tersebut. Secara rata-rata, capaian nilai peserta juga mengalami peningkatan, yaitu sebesar 78,67. Data ini menunjukkan adanya peningkatan yang cukup signifikan dalam pemahaman para santri terkait materi ekonomi dan keuangan syariah.

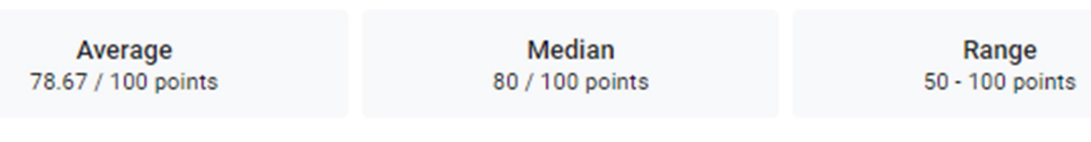

Total points distribution

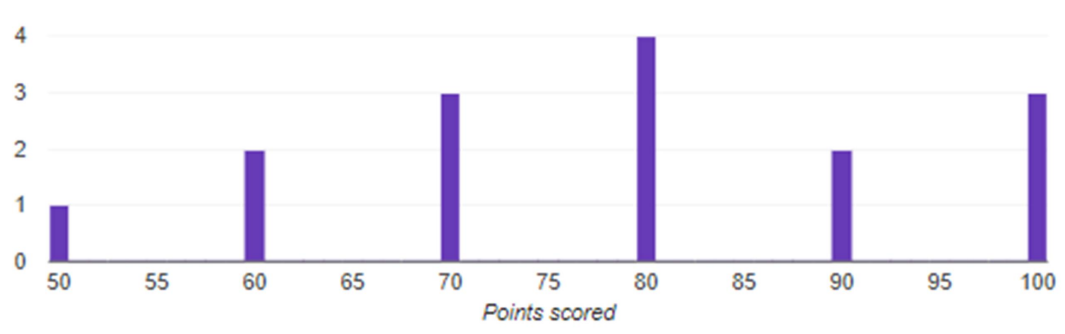

Gambar 5. Hasil Post-Test

Literasi dan edukasi ekonomi dan keuangan menjadi salah satu kunci dalam meningkatkan pemahaman masyarakat (Yushita, 2017). Termasuk dalam literasi ekonomi dan keuangan syariah. Untuk itu, diperlukan berbagai program berkesinambungan terkait edukasi kepada masyarakat yaitu edukasi finansial (Subardi \& Yuliafitri, 2019). Melalui 
langkah tersebut, diharapkan akan mampu mendorong tingkat literasi dan inklusi keuangan syariah di masyarakat. Salah satu upaya yang dilakukan dengan menggandeng institusi pendidikan seperti pondok pesantren untuk mensosialisasikan ekonomi dan keuangan syariah di masyarakat. Hal ini juga dilakukan sebagai bagian dari upaya mendukung pemerintah dalam menargetkan Indonesia sebagai pusat ekonomi dan keuangan syariah dunia.

\section{KESIMPULAN DAN SARAN}

Tingkat literasi dan pemahaman masyarakat terkait ekonomi dan keuangan syariah dapat ditingkatkan melalui berbagai kegiatan edukasi dan sosialisasi yang berkelanjutan. Hal ini menjadi penting untuk bisa meningkatkan literasi sekaligus inklusi keuangan syariah di masyarakat. Berdasarkan instrumen evaluasi yang dilakukan dari tes pendahuluan dan tes penutup, pemahaman peserta terakit ekonomi dan keuangan syariah meningkat sangat baik. Diperlukan upaya dan langkah berkelanjutan untuk terus meningkatkan pemahaman dan kesadaran masyarakat tentang keuangan syariah, yang dimulai dari implementasi praktek dan aktivitas ekonomi sehari-hari.

Berdasarkan hasil temuan dari kegiatan pengabdian ini, disarankan untuk dilakukan adanya kegiatan edukasi dan sosialisasi yang berkelanjutan bagi masyarakat terkait keuangan syariah. Kegiatan tersebut disarankan untuk dapat diselenggarakan dengan mengajak berbagai unsur dari masyarakat yang lebih luas, dan tidak terbatas hanya di lingkungan pondok pesantren. Melalui kegiatan edukasi dan sosialisasi yang berkelanjutan diharapkan akan terbangun ekosistem ekonomi dan keuangan syariah, sehingga mendukung ketercapaian target pengembangan keuangan syariah nasional.

\section{DAFTAR PUSTAKA}

Afandi, T. (2017). Bonus Demografi 2030-2040: Strategi Indonesia Terkait Ketenagakerjaan dan Pendidikan. Kementerian Perencanaan Pembangunan Nasional, 1-2.

Bank Indonesia. (2020). Cetak Biru Pengembangan Ekonomi Syariah. https://www.bi.go.id/id/fungsi-utama/moneter/pengembangan-ekonomi/cetakbiru/Default.aspx

Centre for Strategic and International Studies. (2017). Ada Apa dengan Milenial? Orientasi Sosial, Ekonomi dan Politik. In Survei Nasional CSIS 2017 (Issue November). https://www.csis.or.id/uploaded_file/event/ada_apa_dengan_milenial_paparan_s urvei_nasional_csis_mengenai_orientasi_ekonomi_sosial_dan_politik_generasi_mil enial_indonesia_notulen.pdf

Otoritas Jasa Keuangan. (2019). Survei Nasional Literasi dan Inklusi Keuangan 2019. Survey Report, 1-26. www.ojk.go.id 
Rachmat, M. Baga, L., \& Purnaningsih, N. (2020). Penghimpunan Dana Zakat Infak Sedekah Berdasarkan Intensi Perilaku Muslim Gen Y dalam Penggunaan Teknologi Digital Payment. Al-Muzara'Ah, 8(2), 95-108. https://doi.org/10.29244/jam.8.2.95108

Said, S., \& Amiruddin, A. M. A. (2017). Literasi Keuangan Syariah di Perguruan Tinggi Keagamaan Islam ( Studi Kasus UIN Alauddin Makasar ). Al-Ulum, 17(1), 44-64. https://doi.org/10.9744/jmk.17.1.76

Senjiati, I. H., Anshori, A. R., Siti, I., \& Maulida, R. (n.d.). ( Studi Kasus Pada Siswa Kelas 2 SD Darul Hikam Bandung) Universitas Islam Bandung Literasi mungkin telah banyak orang. Namun tidak banyak dari mereka yang memahami makna dan definisinya secara jelas, sebab menjadi istilah yang familiar bagi literasi m. 33-55.

Subardi, H. M. P., \& Yuliafitri, I. (2019). Efektivitas Gerakan Literasi Keuangan Syariah dalam Mengedukasi Masyarakat Memahami Produk Keuangan Syariah. Banque Syar'i: Jurnal Ilmiah Perbankan Syariah, 5(1), 31-44.

Yushita, A. N. (2017). Pentingnya Literasi Keuangan Bagi Pengelolaan Keuangan Pribadi. Nominal, Barometer Riset Akuntansi Dan Manajemen, 6(1). https://doi.org/10.21831/nominal.v6i1.14330 